\title{
スポーツ選手の食養について \\ Studies on Nutrition of Athletes
}

(昭和 27 年 9 月 4 日受理)

山岡誠 一

(Seiichi Yamaoka)

\section{鍺論}

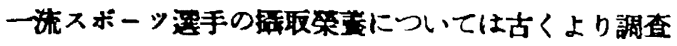

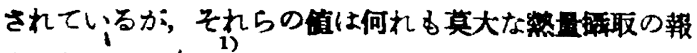
告である。Schenk (1936) (第11回オリンピック大會 (Berlin) に出场した 42 力國 4,700人の選手の掫取榮答 は, 本均 1 日 7,300 Cal, 蛋白 $320 \mathrm{~g}$ であつたと啹告して

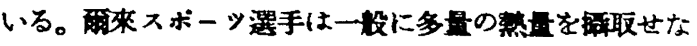
ければならないに思われていた。しかし Berry その 他 (1949) か第 14 回の London におけるォעンピック

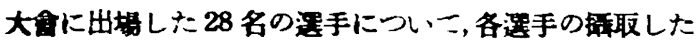
食品盖㑯は，平均 1 日 3,350 Cal. (2,113-4,739 Cal), 蛋 白 $139 \mathrm{~g}$ であつたと報じている。この值は Schenk の般 苦の约牛贯にあたる。Berry 等のこの調查は，各選手

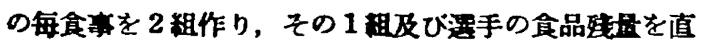

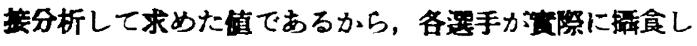

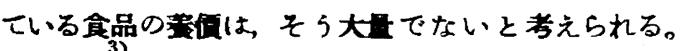
Abraham すスボーシマンのエネルギー代謝量は從來考 メられた程多くないと言つている。

從來我力國においてはスボーツ選手についてのかかる

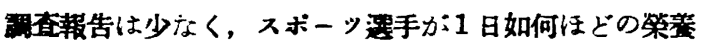
を維取すれば良いかの规集か洤くない゚。スボーシ選手の 合理的な健康管理をなす上には單に括取㮡蓄の調查のみ

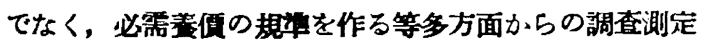
が必要である。そこで著者は如上の目的に從つて, 野球・

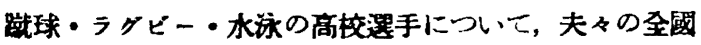

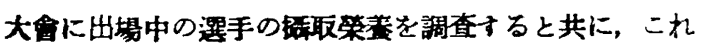
らの大會時の選手 1 日の消费䇾を湘定して，スボーッ 選手の築荟管理上に必要な知見を得たので報告する次第 である。

\section{調査方法}

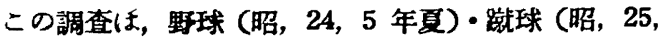
6 年冬)・ラグビー(昭 26 年冬)・水泳 (昭 26 年面)の 圣國高校選手概大會 (水泳( 出锡した選手について行つた。その調査方法は，蹴球・ ラグビー・水泳選手についこは，各大會期間に數チーム
の選手につき，それらの選手の各宿舍主に恢賴して各チ 一ムの食事についての調理献立表を求め，別に選手の間 食の調查を行つた。但し野球のA校のみについては，层 取せる全食品の生のままの容量を值接科量した。そして 正確を期するためには各選手の食品残贯の調查が必要で あるが，宿舍訪問先の他により各選手共主要食品につ、

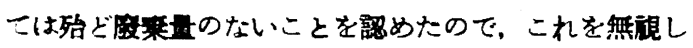

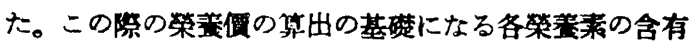

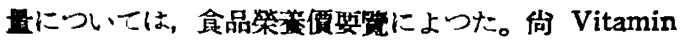
類について含有量の記俄の無い食品では，類似食品の含 有量によつて計算した。かくし二各大會出場選手 1日の 掫した繁量・蛋白・脂肪の榮荟僄及び Vitamin A, $\mathrm{B}_{1}, \mathrm{~B}_{2}, \mathrm{C}$ の摡取盘をチーム每に求め，各理目選手の平 均檤を算出した。

一方掫食䓡量についで，その量の過不足を檢討するた めに，選手 1 日の消霓䓡量をタイムスタデーの結果よ り， R. M. R. その他の指数を用いて算出したのである が，これ等の方法及びその成綪は既に報苦したので，本

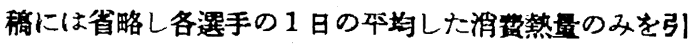
用した。

\section{調 査 成 績}

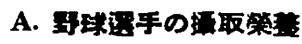

昭和 24 年夏の全國高校野球選手權大曾に際し A 及び $\mathrm{H}$ の 2 校 (18 名), 並びに 25 年度の同大會の直前の合宿 練替期に 6 チームの選手について行つた令躡調查の結果 は，第 1 表に示した㥞である。㞷記の値は华均値とその 標準偏差である。表により見られるA校の値は，宿舍に 括いて調理前の食品を科量して算出したのであるから最 も停賴し得る値である。即ち 8 月 12 日より 17 日まで 6 日間の拪食警量は日により多少の差巽はあるが，本均す ると 1 日 3,900 Cal であつて, 㨐食䓡量の大部分は白米 (1 日 6 合)によるものであり，粎 $70 \%$ の 2,700 Cal は

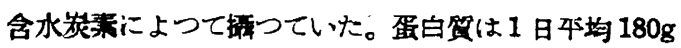
でその $30 \%$ 動物性蛋白であつだ。この蛋白量は A 校 選手の4゙均體重は $56.7 \mathrm{~kg}$ であつたので, 體重 $1 \mathrm{~kg}$ に對 し蛋白 $3 \mathrm{~g}$ 强の給與となつている。 


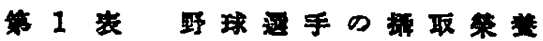

\begin{tabular}{|c|c|c|c|c|c|c|c|c|c|c|c|c|c|c|c|c|}
\hline \multicolumn{2}{|c|}{ 项 } & 目 & 淤 数 & 平 均 & 然 表 & \multicolumn{2}{|c|}{$\begin{array}{l}\text { 鬲白覃 } \\
\text { (金) }\end{array}$} & \multicolumn{2}{|c|}{ 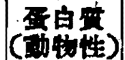 } & 睧 & 助 & V. A & V. $B_{\mathfrak{l}}$ & V. $\mathbf{B}_{\mathbf{2}}$ & $\mathbf{V}$ & c c \\
\hline 大 & $\mathbf{A}$ & 玟 & 6 日 & $\begin{array}{r}\mathrm{kg} \\
56.7\end{array}$ & $\begin{array}{r}\text { Cal. } \\
3,922 \\
\pm 1,228\end{array}$ & \pm & $\begin{array}{r}\mathrm{g} \\
179 \\
33\end{array}$ & \pm & $\begin{array}{r}\mathrm{g} \\
52 \\
18\end{array}$ & & $\begin{array}{r}\mathbf{g} \\
50 \\
18\end{array}$ & $\begin{array}{r}\text { I.U. } \\
2,612 \\
\pm 1,314 \\
\end{array}$ & $\begin{array}{r}1, \gamma \\
\pm^{1,363} \\
\end{array}$ & $\begin{array}{r}879 \\
+\quad 129\end{array}$ & $=$ & $\begin{array}{l}\overline{m g} \\
41 \\
13\end{array}$ \\
\hline 间 & $\mathbf{H}$ & \# & 4 日 & 57.8 & $\begin{array}{r}4,440 \\
\pm \quad 356\end{array}$ & \pm & $\begin{array}{r}172 \\
18\end{array}$ & \pm & $\begin{array}{l}85 \\
26\end{array}$ & \pm & $\begin{array}{l}62 \\
26\end{array}$ & $\begin{array}{r}1,689 \\
\pm \quad 521 \\
\end{array}$ & $\begin{array}{r}2,338 \\
\pm \quad 444\end{array}$ & $\begin{array}{r}1,312 \\
\pm \quad 144\end{array}$ & & 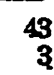 \\
\hline 钮 & 급 & 期 & $\begin{array}{c}6 \\
\text { 远24日 }\end{array}$ & 53.8 & $\begin{array}{r}3,463 \\
\pm \quad 222 \\
\end{array}$ & \pm & $\begin{array}{r}125 \\
17\end{array}$ & \pm & 0 & \pm & 12 & $\begin{array}{r}964 \\
\pm \quad 383 \\
\end{array}$ & $\begin{array}{r}1,855 \\
\pm \quad 686\end{array}$ & $\begin{array}{r}555 \\
\pm \quad 108\end{array}$ & & $\begin{array}{l}47 \\
32\end{array}$ \\
\hline
\end{tabular}

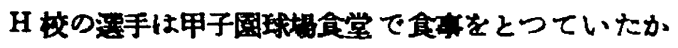

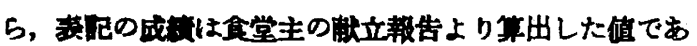

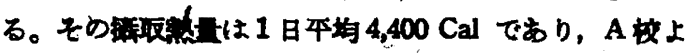
り粎 $13 \%$ 多いしかし雨校の宿舍に同宿して選手の食

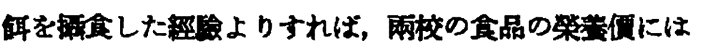
大差を感じなかつたことから，これは旅馆主の獻立報告

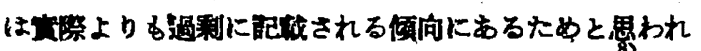
る。このことは昭和 23 年度の同大食に括、て, 井上か泏 媎全チームについてその宿舍主の献立報告より算出した 成䩀では，整量 $3.850 \mathrm{Cal}$ 蛋白 $153 \mathrm{~g}$ であり，24 年度に

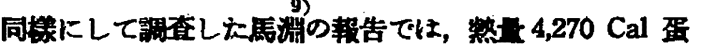
白 $153 \mathrm{~g}$ となつているのを見てす，同汬の傾向がうかが われるのであつて，何れすA校の測值に比して通に大 である。從うて單なる献圤よりの調查はよ注ど虽重に制 盺しないと潩つた結侖に陷る琹れのあることに注意を要 ナる。

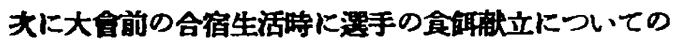
マネージ+ーの報告 (この献站は各チームが㨁接粨理し ている炏事であるから相雷伯赖し得る)では，6 チーム 24 日分を本均すると，繁量 $3,460 \mathrm{Cal}$ 蛋白 $125 \mathrm{~g}$ であつ た。しかしこの值はチームによつて差があり，熱量では $3,160 \mathrm{Cal}$ 上り 3,800 Cal に亘り, 蛋白は $95 . \mathrm{g} よ り 150$ gに及んでいた。

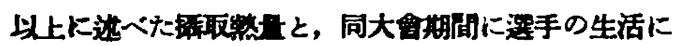

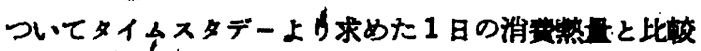
してェネルギーの出納を考察ナるに，甲于国に於ける大

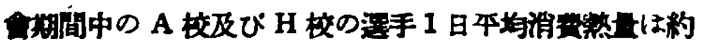

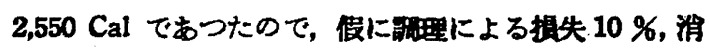

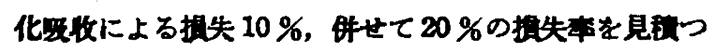

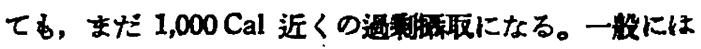

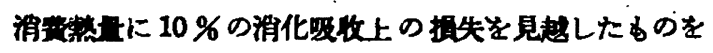

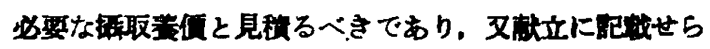

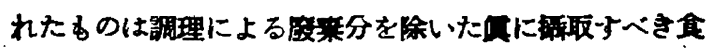
品の生のままの目方であるべきである。從つて正面に辩

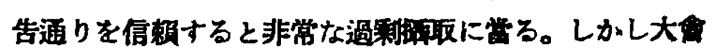

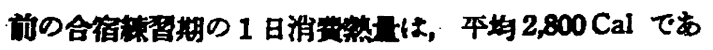

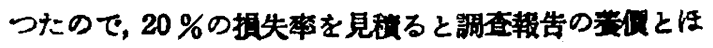

ぼェネルギー出釣の本街を保つていたことたなる。從つ

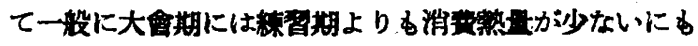

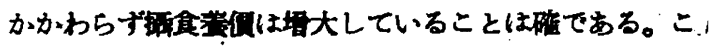

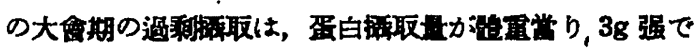
あることについてもいえる。かかる大會期间の週制据取 は必然的に消化器官の負据を過直にするものであつて,

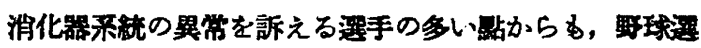
手の大苓期の過食は特に注意せねばならぬ閴題である。

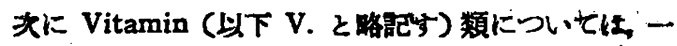
般に青果・兴䋾野荣類の献立か沙なく，大會期のA 校で は表に示した如く特に V. A 及び V. B 年期の必要贯にす達していなかつた。運動選手では更に 多贯に興えることが必㴗である。併し大部分のチームは

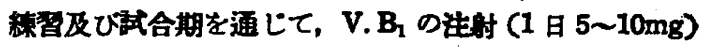
が行かれ, 又 V.C の住待老なしているチームが8チー ム中 4 チームを思めたa

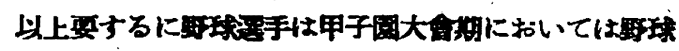

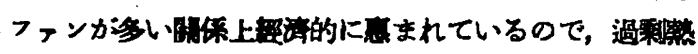

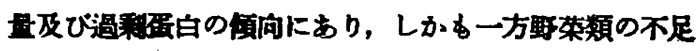
に陷つていると面らべきであろら。

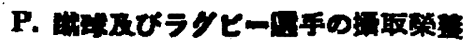

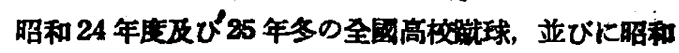

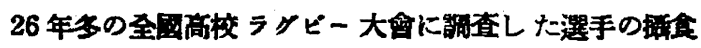

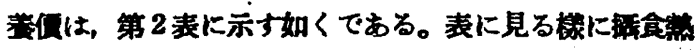

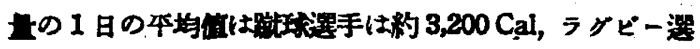
手は3,380 Cal であつだがしかしこの值はチームによつ て差があり，踪手では2,900 Cal から 3,400 Cal に及 んでいた。同大合期間中に湘定した滦手 1 日の生理的洞

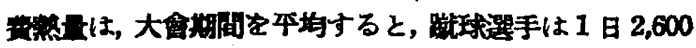
Cal, ラダピー泡手は2,650 Cal であつたから，調理や消

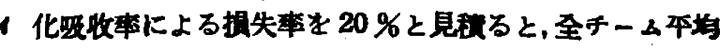
した值では蹜瑝及びラグビー゙選手共，エネルギー出納の

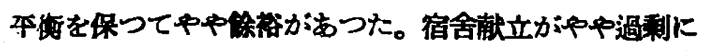
報告せられたがしいないが，選手の主酷的な虑じから

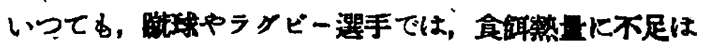
なかつたと宩えられる。

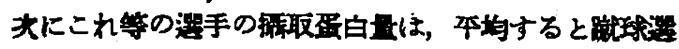




\begin{tabular}{|c|c|c|c|c|c|c|c|c|c|c|c|c|c|c|c|c|c|c|}
\hline 顼 & & & 目 & 例 数 & 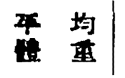 & 热 复 & $\begin{array}{l}\text { 蛋白 } \\
\text { (全 }\end{array}$ & & (登占 & 要性) & 脂 & 眆 & V. $A$ & V. $B_{1}$ & & $\mathrm{~B}_{2}$ & & C \\
\hline 骁 & & - & 球 & $\begin{array}{l}5 \\
\text { 越20日檍 }\end{array}$ & $\begin{array}{r}\mathrm{kg} \\
57.5\end{array}$ & $\begin{array}{r}\text { Cal } \\
3,189 \\
\pm \quad 198\end{array}$ & \pm & $\begin{array}{r}r \\
111 \\
15\end{array}$ & & $\begin{array}{r}\mathbf{g} \\
35 \\
3\end{array}$ & \pm & $\begin{array}{r}8 \\
30 \\
4\end{array}$ & \begin{tabular}{|r|} 
I. U. \\
3,256 \\
\pm 3.710
\end{tabular} & $\begin{array}{r}1,188 \\
\pm \quad 501\end{array}$ & \pm & $\begin{array}{r}\gamma \\
598 \\
128\end{array}$ & \pm & $\begin{array}{r}\mathrm{mg} \\
72 \\
45\end{array}$ \\
\hline ; & 5 & $\varepsilon$ & - & $\begin{array}{l}5 \\
\text { 孥21日 }\end{array}$ & 6.11 & $\begin{array}{r}3,375 \\
\pm \quad 472\end{array}$ & \pm & $\begin{array}{r}100 \\
14\end{array}$ & \pm & $\begin{array}{r}26 \\
8\end{array}$ & \pm & $\begin{array}{l}34 \\
14\end{array}$ & $\begin{array}{r}2,324 \\
\pm 1,337\end{array}$ & $\begin{array}{r}1,057 \\
\pm \quad 175\end{array}$ & \pm & $\begin{array}{r}539 \\
65\end{array}$ & \pm & $\begin{array}{l}51 \\
29\end{array}$ \\
\hline
\end{tabular}

手は1 日 $110 \mathrm{~g}$ (內動物性 35g), ラグビー選手は $100 \mathrm{~g}$ (內

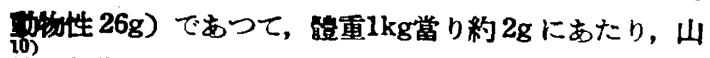
地の報告になる勞作時の必需蛋白量に微して適貫である

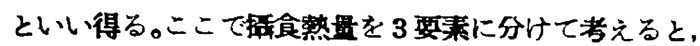
䟽球・ラグビー選手共全䓡埴の 77〜 78％は含水炭素に

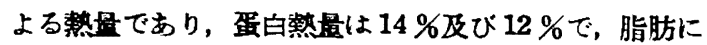
よる熱量は共に $9 \%$ あらつた。さきの野球の例について すこれと同様の配分であるから，我が國のスボーツ選手

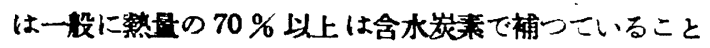
がかか。

夹に Vitamin 䫓であるが V.C 以外は野球と同栐 ボーツマンの青年としては充分とはいえない。V. B 不足を注射に上つて㭪つているチー人は䟽球・ラグビー 合せて11チーム中 4 チームであつた。そして表記の V. A 及び V.Cは，その大部分は人荌及びホーレン草によ つて取つていたのであるか，これもチームにより, 侗 一チームであ日により差か非常に大であつた。野球選手

\section{と同栐 Vitamin 類の粭盖に留意すべきである。}

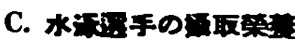

昭和 26 年夏の 西日本高校水泳灌手椎大會は天理ブー 几で行われた。選手は教會詰所に合宿して各選手共同一 の食慨をう。。大全期 2 日間の詰所会堂の献立 (数會 詰所の直炇食堂のため信赖し得る）上り算出した食品羡

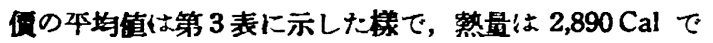

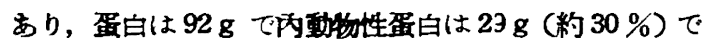
あつた。脂肪の揤取量は前述の野球やラグビーに比して

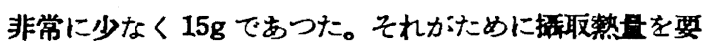
素に分けると，含水炭素か; $82 \%$,蛋白 $13 \%$, であり, 脂 肪の䇾量は $5 \%$ となつていた。この大會期間中の選手の 生活動作のタイムスタデー上り算出した選手 1 日の消密 熱量は，練習や試合を除くと約 $2,000 \mathrm{Cal}$ であつて,試合 時の消貝䓡量は選手の出場種目や回数によつて, $50 \mathrm{Cal}$
(短距襍出場 1 回) 加5 $700 \mathrm{Cal}(1500 \mathrm{~m}$ 自由型出場 2 回)に及び，個人差が大であるので一律にェネルギー出 納を考えることは出來ない。'しかし全般的に見て多くは

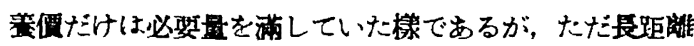
選手の消算整量は1.日2,800 Cal に及び食堂献立のみの 䓡贯では不足である。この不足䓡艘は知卯・バン等の間 食によつて補つていた。

大に食堂献立では，野荣類力殆どなく，第3表に示し た㦈に何れの Vitamin 類も不足している。從つて選手 の大部分は V. B 1 (5〜10mg) の注射をなし, 又一部選 手はV.C あ注射により補つていた。水泳選手について もVitamin の補給には留意すべきである。

要一るにこの水泳大會に批ける選手の擗取榮茨はさき の野球選手のそれに比し對䊈的に極めて务烈であると官 える。前記の棦に過食に陷ることはかえつて選手のコン デションを乳して繁害があるが，この水泳大會の機に策 養の不底なのもいけないことは言らまですない。これら の現象は從來，スボーツの試合や練習に祭しては單に技 街の指導のみに重點が括かれ，これらの技街を發挥すべ き健康上のコンデションについての留意に缺けているこ とに外ならぬ。

\section{總括}

全國高校野球・踧球・ラグビー及び西日本高校水泳選 手權大會に際し, 出場選手に一ついての食餌調查の結果方 の成精を得た。

1. 野球・䟽球・ラグビー及び水泳選手の大會期の 1

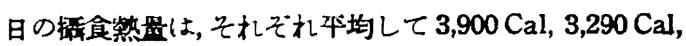
3,380 Cal 及び 2,900 Cal であつた。これらの養價は全 選手の平均の 1 日の生理的消薙盘に比較すると充分エ ネルギー出絧を保つてな和餘裕あるすのである。しかし

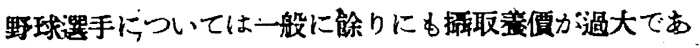

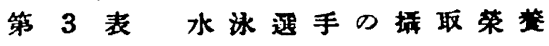

\begin{tabular}{|c|c|c|c|c|c|c|c|c|c|c|c|c|c|c|c|c|c|c|}
\hline 項 & 目 & 例 & 数 & 本 & $\begin{array}{l}\text { 均 } \\
\text { 重 }\end{array}$ & 熱 聐 & $\begin{array}{l}\text { 蛋白 } \\
\text { (全) }\end{array}$ & & 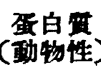 & 脂 & 肪 & V. A & V. & & v. & $\mathbf{B}_{2}$ & v. & C \\
\hline 水 & 泳 & 2 & 日 & & $\begin{array}{r}\mathrm{kg} \\
55.9\end{array}$ & $\begin{array}{r}\text { Cal } \\
2.889 \\
\pm \quad 44\end{array}$ & \pm & $\begin{array}{r}g \\
92 \\
5\end{array}$ & $\begin{array}{r}89 \\
+\quad 29\end{array}$ & \pm & $\begin{array}{r}g \\
15 \\
4\end{array}$ & $\begin{array}{r}\text { I. U } \\
246 \\
\pm \quad 190\end{array}$ & \pm & $\begin{array}{r}\gamma \\
998 \\
112\end{array}$ & \pm & $\begin{array}{r}\gamma \\
636 \\
145\end{array}$ & \pm & $\begin{array}{r}\mathrm{mg} \\
13 \\
1\end{array}$ \\
\hline
\end{tabular}


つて，過食の慜に陷つている。これに對して水泳の長距

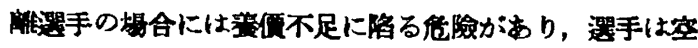

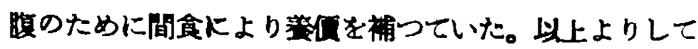
一般にスポーツ避手は一部の過食の選手を除き，從來考

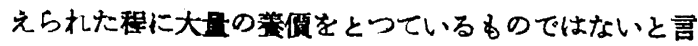
えよ5。

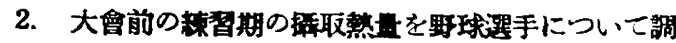
亘した結果はチーム本均 1 日 3,460 Cal であつて，おお

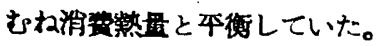

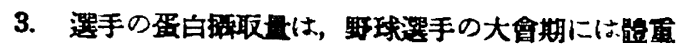

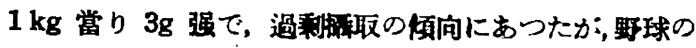

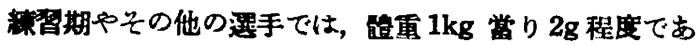

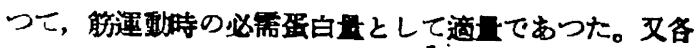
澄手共動物性蛋白は總蛋白每の䄪 $\frac{1}{3}$ 量であつた。

4. これら大倉出場選手の熱量源としての要素の割合 は，含水炭素が 70〜82\%，蛋白䓡量は12〜19\%，脂肪 慗量は5〜13\%であつて，䓡量の大部分は含水龙素（白 米)にて樶っていた。

5. 選手の会触では，一般にVitamin 類に不足を感 じた。特にV.A 及び B，の不足が大であつた。野球及 び水泳手の大部分は，V.B 及 及び V.C の注射を行い， ラタピー及ひ赔球珙手では一部のチームでV. $\mathrm{B}_{1}$ の注射

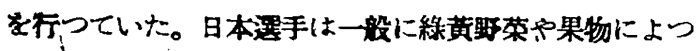
て Vitamin 類の㭪垥に留意与へきである。

6. 促來選手の楝替期や試合間の生活並びに行動は,

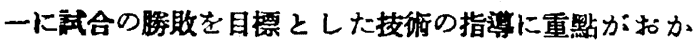
れ,これらの技街を發挥すべき個人の健康狀態の指㝵に は甚け缺けた點が多い。ここに報告した成转はこの目點 をついたのであつて，將來のスボーシ選手の指望に當

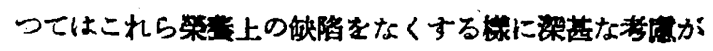
必新である。

本研究の一部は文部省科學研究费に上るるのです

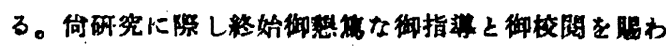

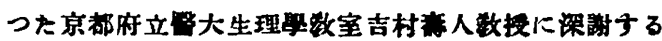
と其に，测定の便宜を興えられた大會筒保者及び各出

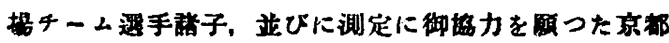

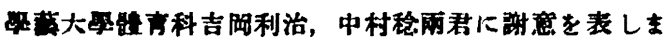
†。

\section{考文辣}

1) P. Schenk: Die Verpflegung von Wettkampfern aus 42 Nations in Olympischen. (1936) Berlin.-

2) W. T.C. Berry, J. B. Beveridge, E. R. Bransby, A. K. Chalmers, B. M. Needham and H. E. Magse: (1949) Brit. Med. J. No. 4598300.

3）2上り引用。

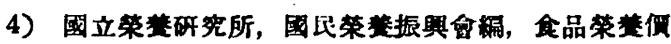
要策 (1945)，第一出版株式合社刊。

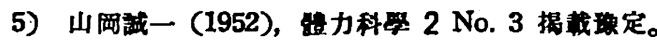

6) 山周誠一他 9 名 (1951), 锚有學研究 No. 2, 174

7) 山阔誠一他 7 名 (1952), 亭學研究 No*3, 220

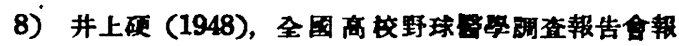
告 (大阪)。

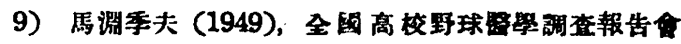
報告 (大阪)。

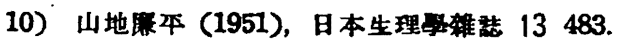

(京都府立管科大祭生理學数室)

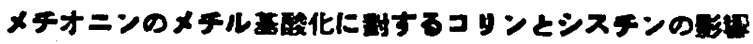

メチオニンのメチル基が生娟內て醏化されて $\mathrm{CO}_{2}$ にな

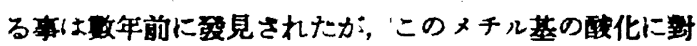

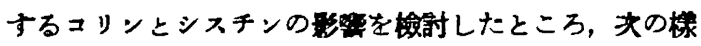
な結果を得た。

即ち 115 130g の雄鼠に䍌し 2.5 涸間これらの榮㝨萧 の缺けた倉聑を投與し，メチル基 $\mathrm{C}^{14}$ メチォニン $2 \mathrm{mg}$ を图管によつて興光, 24 時間內に排出される $\mathrm{C}^{14} \mathrm{O}_{2}$ 盘を 训定したところ，基焚食にコリンを加えたものは，基碟 全のみのすのに比して $\mathrm{C}^{14} \mathrm{O}_{2}$ 發生量力构 3 倍の多きに達
した。をころがンリンの外にシスチンを同時に投與した ものではこの投與堵加は見られず， $\mathrm{C}^{4} \mathrm{O}_{2}$ 排出量は基碩 食のみのものと全く同じであつた。

この事から，シスチン缺乏の狀態ではメチル基の䣬化

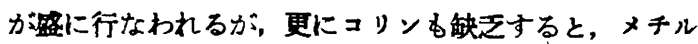
基供與踣及び S-含有〉ミノ酸がメチオニンのみとなる ので，そのメチル基の酸化か浙制されることがわかる。

C. G. Mackenzie, V du Vigneaud.: J. B.C., 195487 (1952) (小池) 